7 Immelman K. Role of the environment in reproduction as source of "predictive" information. In: Farmer DS, ed. Breeding biology of birds. Washington DC: National Academy of Sciences, 1973:121-47.

8 Hoffman K. Photoperiodism in vertebrates. In: Aschoff J, ed. Handbook of behavioural neurobiology. New York: Plenum Press, 1981:449-73.

9 Moore RY. The innervation of the mammalian pineal gland. In: Reiter RJ, ed. The pineal gland and reproduction. Basel: Karger, 1978:1-29.

10 Lewy AJ, Wehr TA, Goodwin FK, Newsome DA, Markey SP. Light suppresses melatonin secretion in humans. Science 1980;210:1267-9.

11 Hastings MH, Herbert J, Martensz ND, Roberts AC. Melatonin and the brain in photoperiodic mammals. In: Evered D, Clark D, eds. Photoperiodism, melatomin and the pineal. London: Pitman, 1985:57-77.

12 Wehr TA, Jacobson FM, Sack DA, Arendt J, Tamarkin L, Rosenthal NE. Phototherapy of seasonal affective disorder. Arch Gen Psychiatry 1986;43:870-5.

13 Murphy $D$, Abas $M$, Checkley SA. Sensitivity to light in seasonal affective disorder. In: Thompson C, Silverstone T, eds. Seasonal affective disorder. London: CNS Neurosciences (in press).

14 Winton F, Corn T, Huson LW, Franey C, Arendt J, Checkley SA. Effects of light treatment upon mood and melatonin in patients with seasonal affective disorder. In: Thompson $\mathrm{C}$, Silverstone T, eds. Seasonal affective disorder. London: CNS Neurosciences (in press).

\title{
Crisis in the National Health Service
}

On 7 December the presidents of the Royal Colleges of Physicians, Surgeons, and Obstetricians and Gynaecologists issued the following joint statement

Each day we learn of new problems in the NHS-beds are shut, operating rooms are not available, emergency wards are closed, essential services are shut down in order to make financial savings. In spite of the efforts of doctors, nurses, and other hospital staff patient care is deteriorating. Acute hospital services have almost reached breaking point. Morale is depressingly low.

It is not only patient care that is suffering. Financial stringencies have hit academic aspects of medicine in par- ticular, because of the additional burden of reduced University Grants Committee funding. Yet the future of medicine depends on the quality of our clinical teachers and research workers.

Face saving initiatives such as the allocation of $£ 30 \mathrm{~m}$ for waiting lists are not the answer. An immediate overall review of acute hospital services is mandatory. Additional and alternative funding must be found. We call on the government to do something now to save our health service, once the envy of the world.

SIR RAYMOND HOFFENBERG IAN P TODD SiR GEORge PINKER

\section{Regular Review}

\section{Community care I: problems}

\author{
ELAINE MURPHY
}

In December 1986 the Secretary of State for Social Services announced that Sir Roy Griffiths would undertake a review of community care. His report is expected early in the New Year. The announcement that Griffiths was to conduct a review caused both hopeful excitement and sceptical anxiety among professionals struggling to develop community based services for people with chronic health problems. The "nonacute" sector of the health service hopes that he will recommend innovations that will have as much impact on community services as the first Griffiths report had on National Health Service management. ${ }^{1}$ His terms of reference are "to review the way in which public funds are used to support community care policy and to advise on the options that would improve the use of these funds as a contribution to more effective community care." Sir Roy has advisers with an interest in community care and is supported by a small departmental team of administrators.

The King's Fund has meanwhile produced its own evidence and recommendations to Griffiths in the form of two memoranda, Facilitating Innovation in Community Care and Making a Reality of Community Care, which draw together the fund's wide knowledge and experience. ${ }^{23}$ Three other reports will be influential in shaping the final report: firstly, the well publicised report from the Audit Commission, Making a Reality of Community Care, ${ }^{4}$ which suggests major reforms in the statutory services; secondly, the report of the Joint Working Party on Public Finance and Residential Care, Public Finance and Residential Care (the Firth report), ${ }^{5}$ which has recommended a substantial change in the way supplementary benefit is used to support 